\title{
Correlation of Multiple Intelligences With Science Learning Attitude in Junior High School
}

\author{
Ardi $^{1 *}$ Narada Hana Nurfadhilah ${ }^{2}$ \\ ${ }^{1}$ Dept. of Biology, Faculty of Mathematics and Science (FMIPA), Universitas Negeri Padang, Padang, Indonesia \\ ${ }^{2}$ Graduated Program of Biology Department Faculty of Mathematics and Science Universitas Negeri Padang, \\ Padang, Indonesia \\ *Corresponding author. Email: naradahnf@gmail.com
}

ABSTRACT

Multiple intelligences is one of the theories of intelligences got a lot of recognition lately. This theory was created by Howard Gardner, a psychologist from Harvard. At first Gardner found seven types of intelligence but then develop it into eight, and discuss the possibility of intelligence ninth. This multiple intelligence has a correlation with learning attitudes of students. Especially in science subjects. Science is a subject that trains many students' intelligence so that it finally shapes the learning attitude of the students themselves. This is a descriptive research of correlation that aims to reveal how the correlation between multiple intelligences and the science learning attitude of students. This research was conducted on January in grade VII SMPN 33 Padang lessons year 2018/2019. The sample consisted of 32 students in one class, VII 4. Sampling technique is simple random sampling, by drawing one class which was made of a sample. The results of the study indicate anot correlation between multiple intelligences and the science learning attitude of students with a value of $r=0,28$, the coefficient of the $t$-count was 1,70 smaller than the t-table of 2,04, so it can be concluded that there is not significant correlation between multiple intelligences and the science learning attitude of students but there are some intelligences that have a relationship with the value of learning attitude science of students in class VII 4 of SMPN 33 Padang.

Keywords: Multiple Intelligences, Science Learning Attitude

\section{INTRODUCTION}

Education is a basic need of every individual who is an inseparable part of each individual. Education is said to be a determinant of the direction of development and selfrealization of individuals according to their personal needs and the needs of society, especially for the development of the nation and state. Ulfah (2013: 112) says that as living things need education in accordance with their desires, meaning different individuals will have different attitudes in study. In addition to different attitudes, individuals also have different levels of absorbing ability. In general, the education that is obtained and received by each individual whether it is obtained at school, at home and in the environment is deliberately carried out to provide opportunities or rights for each individual to optimize their ability to develop their talents.

One of the characteristics of learning is that individuals will experience changes including aspects of behavior. Individuals who have gained their right to learn and gain knowledge as a result will see changes in behavior as a whole, namely changes in attitudes that will be realized, changes in the skills that will be displayed, as well as knowledge that will be mastered. In this regard, in learning the ability and catch ability of students varies. Uno (2008: 180) states that there are students who have the ability to receive learning material as a whole, and there are those who only get a portion of the material and some do not even get their rights in learning. This relates to the attitude of learning and the learning process of students in responding to learning material.

In learning there will be such a thing as a learning process. According to Nurjan (2009: 20) the learning process referred to here is that individuals will make learning a habitual thing which, according to him, is their will that they always want to fulfill. According to Waworuntu (2008: 10) in the learning process in school teachers have many roles, including: the teacher has the authority to direct students according to their abilities, try to make students confident, try to motivate them to live independently, and be able to adjust to student progress. To make it easier to carry out this role, teachers should know the condition of the students, namely knowing the physical condition and psychological condition of the students. Teachers and the government are the parts who participate in improving the learning process and the quality of education of students. The government is always trying to improve the quality of education.

One of the government efforts that we can see in improving the quality is the revision or development of the education curriculum. (Widestra, et al (2017: 49). The last revision was Curriculum 2013 (K13) which started with the Education Unit Level Curriculum (KTSP) in 2006. We need to know that in this 2013 curriculum soft kill and hard skills were more emphasized to improve and balance 
which includes aspects of competence in attitudes, skills and knowledge. In this connection Machali (2014: 21) conducts research to reveal the relationship between this K13 and the theory of multiple intelligences (compound intelligence) that was first coined by a humanistic psychologist namely Howard Gardner, Machali's research results show that K13 does include the development of the multiple intelligences dimension that can be seen from the four Core Competencies (KI) of students. That we need to know that the four Core Competencies are spiritual attitudes, social attitudes, knowledge, and skills.

The psychological condition of the students is intelligence. Intelligence is something that is owned by each individual. Intelligence can be interpreted as a capability, each individual in dealing with and finding solutions to the various problems they face. In this regard Gardner (Chatib, 2011: 75) states that a person's intelligence has many dimensions or can be called multidimensional, and also stated that each individual has each intelligence with a different level of development. Intelligence tendencies are nine intelligences as follows, linguistic intelligence, logical-mathematical intelligence, musical intelligence, kinesthetic intelligence, spatial-visual intelligence, interpersonal intelligence, intrapersonal intelligence, naturalist intelligence, and existential intelligence.

Multiple intelligences (compound intelligence) do not stand out one by one but can stand out one to three simultaneously, meaning that each individual is not only limited to one type of intelligence. Individuals have different types of multiple intelligences. The teacher as a facilitator should know the level of intelligence of students, because the intelligence of students is different. According to Waworutu (2008: 12) as a facilitator, a teacher is able to create good interactions with students so they can know the intelligence of students in learning. Multiple intelligence learners can be known in learning activities at school

Based on observations made by the author at SMPN 33 Padang, the authors suspect that each student has multiple intelligences (compound intelligence) that are different as seen from the varied learning activities in following the learning process, including science learning. In science subjects, students are seen to be trained to have naturalist intelligence, as well as linguistic and interpersonal intelligence. Besides that, it also has kinesthetic intelligence to carry out practical activities, and also has intrapersonal intelligence with the independent task of implementing intrapersonal intelligence. Simanjuntak (2017) said that there is a significant relationship between multiple intelligence components, especially naturalist intelligence, with students' environmental care attitudes. In this regard Simanjuntak states that the attitude of caring for the environment of students $34.1 \%$ is determined by naturalist intelligence, while $65.9 \%$ is determined by other factors. Because of this, the authors conducted a study with variables on learning attitudes in science subjects.

Based on the description that has been presented and the existence of Simanjuntak's findings about the relationship between naturalist intelligence and environmental care attitude, the authors suspect that other multiple intelligences have a relationship with students' learning attitudes, but there is no scientific research that reveals how the relationship between multiple intelligences with learning attitudes Science students especially in SMPN 33 Padang. Therefore, the authors conducted a research to find out how the relationship of multiple intelligences with the attitude of science learning of students at SMPN 33 Padang.

\section{MATERIALS AND METHODS}

Research conducted by researchers is a descriptive correlation study. This study aims to determine how the relationship of multiple intelligences with students' learning attitudes. This research was conducted in April in class VII SMPN 33 Padang in the 2018/2019 academic year. The population in this study was 192 students who were distributed into 6 homogeneous classes. The sample in this study amounted to 32 students who were in one class, namely class VII 4. Simple random sampling is a technique that researchers use for sampling this research, namely by drawing a class that is used as a sample.

The variables in this study consisted of two variables, namely the independent variable and one dependent variable. The independent variable is multiple intelligences. The dependent variable is the learning attitude of science students. The instrument in the study used a questionnaire that was valid and modified from the questionnaire Ganda Hijrah Selaras (2014) and ITC publications with a total of 53 statements. And the learning attitude questionnaire used was modified from the Faculty Education, University of Cambridge (2010) consisting of 25 statements. In this study using the analysis of score conversion, score distribution, normality test and correlation analysis using Pearson Product Moment and Spearman-Rank. Pearson Product Moment to calculate the correlation of normally distributed data and SpearmanRank to calculate data that are not normally distributed. This correlation analysis aims to determine the relationship of multiple intelligences with the attitude of science learning of students. Furthermore, to test the hypothesis in the study, the t test was used and to see the contribution between the two variables using the formula coefficient determinant.

\section{RESULT AND DISCUSSION}

\subsection{Result}

The results of research on multiple intelligences and science learning attitudes can be seen in Table 1 . 
Table 1. Data Normality Test Results

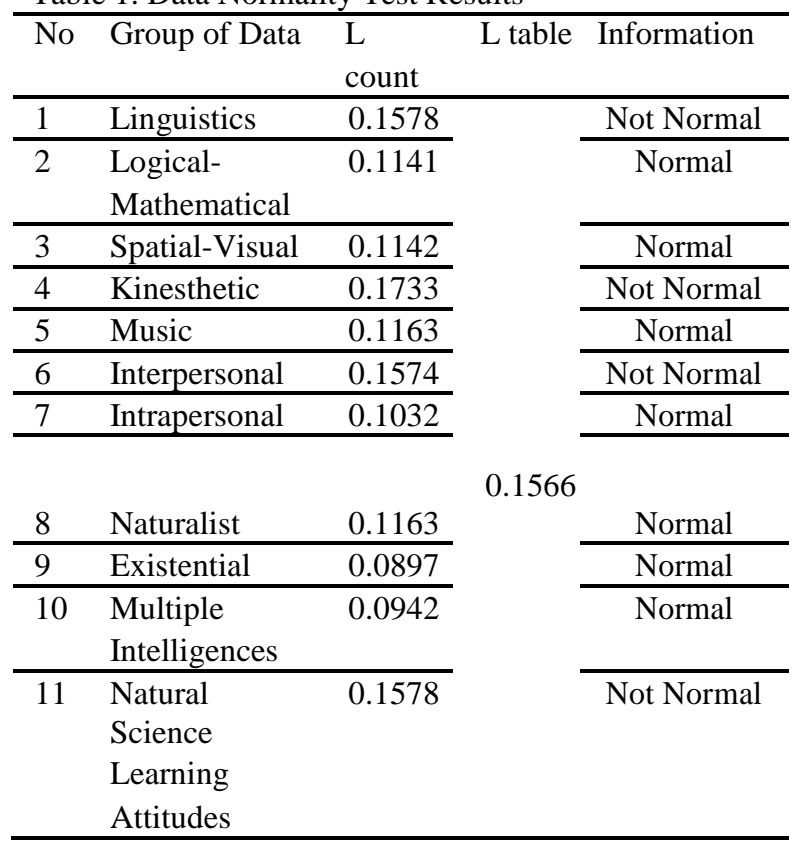

Table 2. Correlation of Multiple Intelligences with Science Learning Attitudes

\begin{tabular}{|c|c|c|c|c|}
\hline \multirow[t]{2}{*}{ No } & \multirow[t]{2}{*}{ Correlation } & \multirow{2}{*}{$\begin{array}{l}\text { Attitudes } \\
\text { Learning } \\
\text { Science }\end{array}$} & \multicolumn{2}{|c|}{$\begin{array}{l}\text { Correlation Correlatio } \\
\text { coefficien }\end{array}$} \\
\hline & & & $\mathrm{t}$ & n Criteria \\
\hline 1 & Linguistics & \multirow{9}{*}{$\begin{array}{l}\text { Attitudes } \\
\text { Learning } \\
\text { Science }\end{array}$} & 0.31 & Weak \\
\hline 2 & $\begin{array}{l}\text { Logical- } \\
\text { Mathematical }\end{array}$ & & 0.45 & Medium \\
\hline 3 & Spatial-Visual & & 0.09 & $\begin{array}{l}\text { Very } \\
\text { Weak }\end{array}$ \\
\hline 4 & Kinesthetic & & 0.31 & Weak \\
\hline 5 & Music & & 0.00 & $\begin{array}{l}\text { Very } \\
\text { Weak }\end{array}$ \\
\hline 6 & Interpersonal & & 0.09 & $\begin{array}{l}\text { Very } \\
\text { Weak }\end{array}$ \\
\hline 7 & Intrapersonal & & 0.55 & Medium \\
\hline 8 & Naturalist & & 0.11 & $\begin{array}{c}\text { Very } \\
\text { Weak } \\
\end{array}$ \\
\hline 9 & Existential & & 0.12 & Very \\
\hline 10 & $\begin{array}{l}\text { Multiple } \\
\text { Intelligences }\end{array}$ & & 0.28 & Weak \\
\hline 11 & $\begin{array}{l}\text { Natural } \\
\text { Science } \\
\text { Learning } \\
\text { Attitudes }\end{array}$ & & 0.31 & Weak \\
\hline
\end{tabular}

Based on Table 2 it can be seen that of the nine intelligences in multiple intelligences that are correlated with learning attitudes in natural science subjects, there are six intelligences that have very weak correlations, two intelligences that have weak correlations, and one intelligence that has moderate correlation with logical intelligence ie mathematical. While overall multiple intelligences have a weak correlation with students' science learning attitudes.

Table 3. Hypothesis Test Results for Multiple Intelligences with Science Learning Attitudes

\begin{tabular}{|c|c|c|c|c|}
\hline No & Hypothesis (T test) & $\begin{array}{c}\mathrm{t} \\
\text { count }\end{array}$ & $\begin{array}{c}\mathrm{t} \\
\text { table }\end{array}$ & $\begin{array}{l}\text { Meaningful } \\
\text { relationship }\end{array}$ \\
\hline 1 & $\begin{array}{ll}\text { Linguisti } & \\
\mathrm{c} & - \\
\end{array}$ & 1.78 & & No \\
\hline & learning attitudes & & & \\
\hline 2 & $\begin{array}{l}\text { LogMat - science } \\
\text { learning attitudes }\end{array}$ & 2.79 & & Yes \\
\hline 3 & $\begin{array}{l}\text { Spa-Vis-science } \\
\text { learning attitudesl }\end{array}$ & 0.53 & & No \\
\hline 4 & $\begin{array}{l}\text { Kinesteti } \\
\mathrm{c} \quad-\quad \text { science } \\
\text { learning attitudes }\end{array}$ & 1.86 & & No \\
\hline 5 & $\begin{array}{l}\text { Music - science } \\
\text { learning attitudes }\end{array}$ & 0.00 & & No \\
\hline 6 & $\begin{array}{l}\text { Interpersonal - science } \\
\text { learning attitudes }\end{array}$ & 0.55 & 2.04 & No \\
\hline 7 & $\begin{array}{l}\text { Intrapersonal - science } \\
\text { learning attitudes }\end{array}$ & 2.15 & & Yes \\
\hline 8 & $\begin{array}{l}\text { Naturalist }- \text { science } \\
\text { learning attitudes }\end{array}$ & 0.63 & & No \\
\hline 9 & $\begin{array}{l}\text { Existentia } \\
1 \quad-\quad \text { science } \\
\text { learning attitudes }\end{array}$ & 0.71 & & No \\
\hline 10 & $\begin{array}{l}\text { MI - science learning } \\
\text { attitudes }\end{array}$ & 1.70 & & No \\
\hline
\end{tabular}

\subsection{Discussion}

The results of research and data analysis about the relationship of multiple intelligences with the attitude of science learning in VII grade students of SMPN 33 Padang is known that multiple intelligences do not have a significant relationship with the attitude of learning of science students. Can be seen from the t-count (1.70) which is smaller than the value of t-table (2.04). The correlation coefficient between multiple intelligences with science learning attitudes of students is 0.28 with a coefficient of determination of $8.06 \%$. Even though the level of correlation is weak, multiple intelligences still have a relationship with the attitude of learning science students, especially in the logical-mathematical intelligence and intrapersonal intelligence. The coefficient of determination of $8.06 \%$ shows that the science learning attitudes of students at SMPN 33 Padang are influenced by multiple intelligences of $8.06 \%$. 
Every intelligence on multiple intelligences that is correlated with the learning attitude of science students, each has a correlation coefficient with very weak to moderate criteria. Teachers need to know the learning attitudes of students, especially in science subjects at the junior high school level, because they support teachers when learning in class, in addition to the learning attitudes of students, multiple intelligences owned by students need to be known and considered by the teacher. This is in accordance with the opinion of Setiawati (2008: 20-21) which reveals that teacher knowledge about multiple intelligences in students can help to optimize understanding of the intelligence profile of students, so that they can optimize the strengths of students to anticipate weaknesses owned by students.

After knowing the level of correlation between multiple intelligences and IPA learning attitudes, a t-test is

\section{CONCLUSION}

The conclusion of this study is that there is no significant and positive relationship between multiple intelligences with the attitude of science learning in grade VII 4 students of SMPN 33 Padang with a t-count of 1.70, at a $95 \%$ confidence level with $\mathrm{db}=30$, smaller than t-table ie 2.04. The correlation between multiple intelligences with science learning attitudes of students is in the weak category with a value of $r=0.28$.

For further research that is to give sufficient time to students when filling out the questionnaire given to students so that students can think of answers to each statement in the questionnaire in accordance with the level of compound intelligence they have.

\section{ACKNOWLEDGMENT}

We thank Ms. Dra. Helendra, M.S. and Ms. Ganda Hijrah Selaras, M.Pd., as a validator and have also been able to give criticism and suggestions for this research.

\section{REFERENCES}

[1] Chatib. M. 2011. Sekolah Manusia. Bandung: Kaifa

[2] Anonymous. 2012. Orangtuanya Manusia. Bandung: Kaifa

[3]Machali, I. 2014. Dimensi Kecerdasan Majemuk dalam Kurikulum 2013. ISSN 1410-0053. Insania, Vol. 19, No. 1

[4] Nurindah, L. 2010. Pengaruh Multiple Intelligences terhadap Hasil Belajar Siswa pada Mata Pelajaran Bahasa Jepang di SMAN 13 Bandung. Skripsi. Bandung: Universitas Pendidikan Indonesia

[5] Nurjan, S. 2009. Psikologi Belajar. Surabaya: Amanah Pustaka performed to find out whether there is a meaningful relationship or not and the results can be seen in Table 3 . Based on the results of the multiple intelligences hypothesis testing with IPA learning attitudes, there are two intelligences which has a meaningful relationship with students' science learning attitudes, namely logicalmathematical intelligence and intrapersonal intelligence. The relationship of logical-mathematical intelligence is in line with research conducted by Nurindah (2010) which results that students who have logical-mathematical intelligence abilities prefer to conduct experiments in laboratory, categorize, analyze data. The other seven intelligences do not have a significant relationship with students' science learning attitudes, namely linguistic, spatial-visual, kinesthetic, musical, interpersonal, naturalist, and existential.

[6] Selaras, G. H. 2013. Hubungan Multiple Intelligences dengan Hasil Belajar Biologi Siswa Kelas X SMAN di Kota Padang, E-Jurnal UNP. Vol. 1, No. 2: 22-34

[7] Anonymous. 2014. Hubungan Multiple Intelligence dengan Hasil Belajar

Biologi Siswa Kelas X SMAN di Kota Padang. Tesis. Padang:

\section{Universitas Negeri Padang}

[8] Setiawati, S. 2008. Proses Pembelajaran dalam Pendidikan Kesehatan.

Jakarta: Trans Info Media

[9] Simanjuntak, H. B. 2017. Hubungan Antara Kecerdasan Naturalis dengan Sikap Peduli Lingkungan Siswa SMPN 7 Bandar Lampung. Skripsi. Bandar Lampung: Universitas Lampung

[10] Ulfah, M. 2013. Hubungan antara Eosional dan Keyakinan Diri dengan Perilaku Belajar Siswa Akselerasi pada Mata Pelajaran Fisika SMAN 3 Sengkang Unggulan Kab. Wajo Provinsi Sulawesi Selatan. Jurnal Pendidikan Fisika. Makassar: Universitas Islam Negeri Alauddin

[11]Uno, H. 2008. Teori Motivasi dan Pengukurannya. Jakarta: Bumi Aksara

[12] Waworuntu, F. 2008. Peran Guru Dalam Proses Pembelajaran Kimia di SMAN 2 Bitung. Jurnal Ilmiah Ilmu Pendidikan 4 (I): 2

[13] Widestra, R. A., Dj. Djamas dan Asrizal. 2017. Pengaruh Model terhadap Kompetensi IPA Siswa VIII SMPN 13 Padang. Skripsi. Padang: UNP. 